\title{
Electronic information resources for medical college libraries available online with special reference to Uttar Pradesh
}

\author{
Iram Khan', Arum Modak², Mohammad Kashif Khan ${ }^{3 *}$ \\ ${ }^{1}$ Researcher, ${ }^{2}$ Associate Professor, ${ }^{3}$ Librarian, ${ }^{1,2}$ Dept. of Library and Information Science, ${ }^{1,2}$ Sri Satya Sai University of Technology and \\ Medical Sciences, Sehore, Madhya Pradesh. ${ }^{3}$ Librarian, Era University, Lucknow, Uttar Pradesh, India \\ *Corresponding Author: Mohammad Kashif Khan \\ Email: kashifonline12@gmail.com
}

\begin{abstract}
This study focuses on Electronic Information Resources for medical college Libraries of Uttar Pradesh, under the study. The studies aim to examine the factors like experience of Electronic information resources such as e-journals, standards, reports, patents, trade reports are available on the web which is widely used by students and researchers. This paper analyzes the use of such electronic resources by the medical college libraries students and researchers of medical college Libraries of Uttar Pradesh, India. Which is one of the premier Medical college libraries in India? The study was done through survey method. The results of the study reveal that the Medical College Library possessed sufficient online journals and databases necessary for the student and researchers. Parameters such as use of library services, purpose of using web resource, frequency of usage place of using web resources, place of web resources, reliability of web resources, assistance for using web resources, barriers and preference of using web resources use of e-reference sources and e-journal database consulted by users are analyzed and results are presented in this paper.
\end{abstract}

Keywords: Electronic Information Resources, Medical College Libraries web- resources, e- resources.

\section{Introduction}

E-resources have become part and parcel of today's research irrespective of the field. Users have their information needs met via number of options. They need not come physically to the library to use print formats but can stay at home or the office and access online library resources and services via networks or authentication methods at any time. Medical information should be accessible, authoritative, reliable, accurate, and timely. Due to the needs of medical professionals for high quality information, medical libraries have been early adopters of electronic resources to provide information and services. Electronic resources have exploded in popularity and use. Medical faculty and students to use eresources include relating to increasingly computer-literate students and keeping up to date in their fields. ${ }^{6}$ The latter is essential for those with clinical practice as more of their clients use e-resources to keep informed about health information. Access to e-resources has decreased the time spent searching for information. The ability to use eresources efficiently depends on basic computer skills, knowledge of what is available and how to use it, and ability to define a research problem. Faculty due to the nature of their work teaching, research, and in some cases, clinical practice should have ready access to medical information. Computer literate faculty and students may feel more comfortable using electronic information sources and thus gain more from using them. How faculty attains the above skills and knowledge depends on many factors, such as their disciplines, academic status and ranks, access to electronic resources and training. The library plays a leading role in faculty - library relationships and in instructional services such as orientation and training in use of library resources. If efficient and effective use is to be made of library's eresources, then user training will have to increase in both intensity and coverage. It is important to remember that the ability of library staff to keep up to date is necessary and therefore training for them is crucial as well. There is a progressive increase in the number of online journals day by day. The different types of users, diversity in the field of research, expecting less time to access the information and availability of web resources at ease have necessitated the growth concept of information searching and the way of determining the search pattern

Libraries carry out different actions such as indexing and abstracting, current awareness services, Selective Dissemination of Information (SDI) and answering of user's queries to ensure that users of the library are satisfied. As the library carries out these functions through information management professionals, the availability of these library resources does not guarantee their access and use by the university community. The university library managers are expected to stimulate, enhance, and sustain the interest of users in visiting the library and using the information contained therein. The knowledge of how to access and use information in the library so as to improve their work can lead to effective librarians' performance in any university system. Library is saddled with much responsibilities which include analysis of patron request to determine needed information and assist in locating that information, search standard reference materials including online resources and internet in order to answer patrons' reference questions, to teach library patrons how to search for information using databases, to keep records of circulation and materials and catalogues in order to select and order print of electronic resources in the library and information centre. ${ }^{3}$

\section{Aim \& Objective of the Study}

The objectives behind conducting present study are:

1. To examine the factors like experience of use of eresources. 
2. To find out various types of electronic information resources used by the faculty and students.

3. To investigate the core medical college libraries databases accessed by the faculty and students.

4. To find out the source of awareness and purpose of use of electronic information resources.

5. To find out the preferred file format of electronic information resources.

6. To find out the overall rating of e-resource collection of the library.

\section{Review of Literature}

Chowdappa, et al. n users rely upon books, journals, CDs and internet for their research and the opinion in the use of digital sources compared to the traditional depicts the extent of dependency of "users of Educational and Research Institute of Mysore city on the electronic/digital media and tried to find out the impact of e-information resources on the academic community". The main objectives was to know how informatio. Kanniyappan, et al. found out the "use of different types of e-resources and services and their impact on the academic development of faculty members at Anna University library, Chennai". Findings indicate that the overall respondents use computers and online services. Majority of them use e-mail, internet, OPAC system and online journals. Lal, et al. studied "uses of internet access by medical students and resident doctors of Maulana Azad Medical College, and found that it has a lower cost as compared to paper-based dissemination of information and also has an added advantage of being available world wide instantly on demand. Therefore, there is a need not only to equip medical fraternity with adequate skills for use of internet but also to make internet facility available in institutions providing medical education and health-care. Manhas conducted a survey on "Use of the Internet and Electronic Resources for Dental Science Information: A Case study". The results of the study reveal that the dental teachers and students $(73.7 \%)$ under study have their own personal computers or laptops. $42.6 \%$ of the respondents use the Internet and electronic resources for finding health/dental sciences information, followed by patient $\mathrm{c}$ are with $26.5 \%$ responses. A majority of the respondents $(80.2 \%)$ feel that the Internet and electronic resources cannot replace the physic al resources (print resources) that it only supplements the print resources. ${ }^{6}$

\section{Scope \& Coverage of the Study}

The study was conducted among the library professionals in medical college Libraries of Uttar Pradesh .There are 67 medical college Libraries in Uttar Pradesh which are under the purview of the present study. As the all medical college is recognized by AICTE, PCI/UGC the study is limited to 67 medical college Libraries of Uttar Pradesh, India.

\section{Methodology}

The scope of the study is restricted only to faculty and students of Uttar Pradesh Medical College Libraries .In this study questionnaire method was used to collect the necessary data, keeping in view the objectives of the study. A total 200 questionnaire were randomly distributed among the faculty and students and 180 filled up questionnaire were received back consisting of good responses. The observation, interview and questionnaire, are used for data collection, the data were analyzed and presents the form of tables and accordingly conclusion are drawn.

\section{Data Analysis}

The data collected by different methods were analyzed, interpreted and same has been presented in the following tables.

Table 1: Source of information about the e-resources

\begin{tabular}{|c|l|c|}
\hline S.No. & Sources of Information & $\begin{array}{c}\text { No. of } \\
\text { Respondents }\end{array}$ \\
\hline 1. & Office circular & $27(15 \%)$ \\
\hline 2 & $\begin{array}{l}\text { Office circular Library } \\
\text { notice board /E-mail }\end{array}$ & $81(45 \%)$ \\
\hline 3 & Colleagues & $54(30 \%)$ \\
\hline 4 & College website & $22(12 \%)$ \\
\hline 5 & College Newsletter & $5(2 \%)$ \\
\hline
\end{tabular}

This table explains the source of information about the eresources by the medical students and faculty. Majority of student and faculty $45 \%$ library notice board and E-mail and used in access the medical related information.

Table 2: Types of e-resources accessed

\begin{tabular}{|l|l|c|}
\hline S.No. & Type of E-Resources & $\begin{array}{c}\text { No. of } \\
\text { Respondents }\end{array}$ \\
\hline 1 & E-Journals & $111(61 \%)$ \\
\hline 2 & E-Books & $47(26 \%)$ \\
\hline 3 & $\begin{array}{l}\text { Bibliographic } \\
\text { databases }\end{array}$ & $17(9 \%)$ \\
\hline 4 & CD-ROM Database & $13(7 \%)$ \\
\hline
\end{tabular}

This table shows that types of e-resources access.61\% respondents access E-journals, $26 \%$ of respondents access Ebooks, $9 \%$ of respondents access Bibliographic databases, $7 \%$ of respondents access CD - ROM Databases. Majority of respondents access in Electronic journals for e-resources.

Table 3: Preferable format for getting information

\begin{tabular}{|l|l|c|}
\hline S.No. & Types of Format & $\begin{array}{c}\text { No. of } \\
\text { Respondents }\end{array}$ \\
\hline 1 & Print & $67(37 \%)$ \\
\hline 2 & Electronic & $20(11 \%)$ \\
\hline 3 & Both & $116(64 \%)$ \\
\hline
\end{tabular}

This table indicates that out of 116 respondents $64 \%$ of them are preferable for getting information from both formats, $37 \%$ of them are from print format and $11 \%$ of them are preferable for getting information form electronic format

Table 4: Frequently accessed of search engine tools 


\begin{tabular}{|l|l|c|}
\hline S.No. & Search Engine Tools & No. of Respondents \\
\hline 1 & Google & $164(91 \%)$ \\
\hline 2 & Opera & $4(2 \%)$ \\
\hline 3 & Yahoo & $20(11 \%)$ \\
\hline 4 & Altavista & $2(1 \%)$ \\
\hline
\end{tabular}

Now a day's various search engines are available for searching information from internet. Hence the investigator tries to find out which is the most commonly used search engine by students and faculty. This table shows that various search engines used by the Chennai medical college hospital and research centre students and faculty. It indicate that majority of the student and faculty using Google $91 \%$ as search engines, $2 \%$ is using Opera, $11 \%$ using in Yahoo and $1 \%$ using in Altavista for searching required information from e-resources. It can be found that Google is most commonly used search engines by the students and faculty because it is fast in access and regularly updated.

Table 5: Use of Medical databases

\begin{tabular}{|l|l|c|}
\hline S.No. & Medical Databases & No. of Respondents \\
\hline 1 & PUB MED & $145(80 \%)$ \\
\hline 2 & PROQUEST & $15(8 \%)$ \\
\hline 3 & IND MED & $14(7 \%)$ \\
\hline 4 & Chemical Abstract & $12(6 \%)$ \\
\hline 5 & SCOPUS & $18(10 \%)$ \\
\hline
\end{tabular}

The use of e-medical databases made accessible via medical college library for the faculty and students has been summarized in the form of this table. It is clear from the table that $80 \%$ respondents use PUBMED, followed by, $8 \%$ PROQUEST 7\% INDMED 6\% chemical abstract and 10\% SCOPUS. This table also shows that majority of $80 \%$ of students and faculty use in PUBMED database

\section{Suggestion}

1. The faculty and students should be trained in using various search options available in search menu of electronic information resources for effective retrieval of relevant information.

2. The web designers / publishers / distributors should provide online help menu in the search page for better utilization of their information resources.

3. The library and information center should send alerts regarding newly available e-resources in print as well as in electronic format.

4. The medical institutions should organize seminars, workshops and

Orientation programmes for faculty and students at regular interval of time to keep them pace with latest information technologies.

\section{Conclusions}

The proliferation of electronic resources has a significant impact in the Medical community uses, stores and preserves information. The analysis shows that electronic resources have become the vital part of information source and being widely used by Uttar Pradesh medical college libraries students and faculty. It has rapidly changed the way of seeking and disseminating information. It indicates that most of the students and faculty are aware about electronics resources and they use this e-resource for searching online required information. Hence there is an urgent need for effective user education, orientation programme, workshops, seminars etc among the Uttar Pradesh medical college libraries students and faculty only they can exploit the maximum benefit from the e-resources

\section{Conflict of Interest}

The authors declare that there are no conflicts of interest in this paper.

\section{Source of Funding \\ None.}

\section{References}

1. Boshorun TM, Abdulmin I, Adisa MY. User perception of electronic resources in the University of Ilorin, Nigeria (UNILORIN). J Merging Trends Comput Inf Sci. 2011;2(11).

2. Mulla KR, Use of Electronic Sources by faculty members in HKBK College of Engineering: A Survey" Libr Philos Pract. 2011

3. Modak A, Gupta S.(2021), Library Automation and Networking in Private University: An Analytical study of Bhopal Division, Madhya Pradesh. South Asia J Multidiscip Stud. 2021;7(3):1-8

4. Naushad Ali PM, Hasan E. The use of electronic services at IIT Library, Delhi: a study of user's opionin. IASLIC Bull. 2003;48(2):71-82.

5. Rehman S, Ramzy V. 'Awareness and use of electronic information resources at the health sciences centre of Kuwait University", Library Rev. 2004;53(3):150-6.

6. Vijayalakshmi R. A Study on Electronic Information Resources Usage Pattern among Students and Faculty in Chennai Medical College Hospital and Research Centre, Trichy. J Adv Libr Inf Sci. 2017;6(3):230-5

7. Sudhier KG, Seethalekshmi K. "Use of E-resources by the Students and Researchers of Faculty of Arts, University of Kerala. Int J Inf Dissemination Technol. 2011;1:205-14.

How to cite: Khan I, Modak A, Khan MK. Electronic information resources for medical college libraries available online with special reference to Uttar Pradesh. IP Indian J Libr Sci Inf Technol. 2021;6(1):17-9. 